\title{
APPLICATION OF TETRAETHYL ORTHOSILICATE MODULAR SYSTEM ON THE PRESERVATION OF ANDESITE TYPE ROCK
}

\section{APLIKASI SISTEM MODULAR TETRAETIL ORTOSILIKAT PADA PELESTARIAN BATU JENIS ANDESIT}

\author{
Nahar Cahyandaru', Esther von-Plehwe Leisen², Hans Leisen ${ }^{3}$ \\ a Borobudur Conservation Office, Ministry of Education and Culture, Indonesia', German- \\ APSARA Conservation Project, Siem Reap, Cambodia ${ }^{2}$ dan Cologne Institute of Conservation \\ Sciences, TH Koeln University of Applied Sciences, Germany ${ }^{3}$ \\ nhrcahyandaru@yahoo.com
}

\begin{abstract}
ABSTRAK
Batuan andesit umum digunakan sebagai penyusun bangunan bersejarah di Asia Tenggara, khususnya di Indonesia. Namun, kajian tentang konsolidasi dan konservasi batuan andesit lainnya masih terbatas. Sebelumnya, penggunaan polimer organik untuk konsolidasi batu tinggalan buday terbukti memiliki efek negatif. Penggunaan konsolidasi etil silikat dalam bentuk sistem modular TEOS (Tetraethyl orthosilicate) diharapkan lebih kompatibel dengan andesit yang terutama terdiri dari mineral silikat karena konsolidasi tersebut diakibatkan oleh terbentuknya silika sebagai pengikat. Sistem mortar pengikat berbasis TEOS merupakan cara konservasi yang telah banyak berhasil diterapkan. Dalam proyek kerjasama lima tahun Balai Konservasi Borobudur (BCO) dengan TH Cologne-University of Applied Sciences, efektivitas bahan konservasi berbasis TEOS pada batuan jenis andesit dalam konservasi tinggalan budaya telah diselidiki bersama. TEOS digunakan sebagai sistem modular untuk impregnasi konsolidasi serta dalam mortar yang dicampur dengan agregat andesit. Sistem mortar andesit-TEOS ini terutama digunakan untuk mengisi celah dan sambungan.

Sistem Modular TEOS berhasil diterapkan pada batuan jenis andesit, menghasilkan sifat kimia dan fisik yang mampu beradaptasi dengan baik dari sampel dan bahan konservasi yang dikembangkan. Warna mortar dan kesesuaian dengan warna batu asli dirancang dari persiapan bubuk batu. Perbaikan yang baik diperoleh dengan kombinasi teknik dot gluing menggunakan resin epoksi dan aplikasi mortar TEOS di bagian celah. Selanjutnya, teknik ini berhasil diterapkan untuk intervensi darurat pada Kepala Buddha besar di Museum Karmawibhangga di Borobudur yang terbuat dari batu andesit.
\end{abstract}

Kata Kunci: Andesit, Konsolidasi, TEOS, Mortar

\section{ABSTRACT}

Andesite rock is commonly used as a heritage building stone in Southeast Asia, especially in Indonesia. However, the study on consolidation and other conservation treatments of andesite rock is still limited. Previously, the use of organic polymers for the consolidation of heritage stones has shown to have negative effects. The use of ethyl silicate consolidation in the form of a TEOS modular system (Tetraethyl orthosilicate) is expected to be more compatible with andesites mainly consisting of silicate minerals because the consolidation is due to the formation of silica as a binder. The application of TEOS-bound repair mortar systems is also a successful way of conservation. In a five-year cooperation project of BCO with the TH Cologne - University of Applied Sciences, the effectiveness of TEOSbased conservation materials on the andesite type rock in heritage conservation was jointly investigated . TEOS was used as a modular system for consolidation impregnation as well as in repair mortars mixed with andesite aggregates. This andesite-TEOS mortar system was mainly used for gap and joint filling.

TEOS Modular System was successfully applied to the andesite type rock, resulting in well-adapted chemical and physical properties of the treated samples and the conservation materials developed. The color of the mortar and the compatibility with the original rock color were designed from the rock powder preparation. The excellent repair was obtained by a combination of the dot gluing technique using epoxy resin and the TEOS mortar application in the gaps. Furthermore, this 
technique was successfully applied for an emergency intervention on the big Buddha Head in the Karmawibhangga-Museum in Borobudur made from andesite rock.

Keywords: Andesite, Consolidation, TEOS, Mortar

\section{PENDAHULUAN}

In Indonesia, andesite-type rocks are often used for monument buildings and sculptures. Due to weathering influences and other damaging impacts stone deterioration is a common concern. In stone conservation, there are different steps to react to material deterioration.

There is a need for conservation conceptions for objects made from andesitic rocks. The study on the consolidation of andesite rock and adapted repair mortar systems is still limited (Widati et al., 2017). Stone consolidants and binder systems for mortars play the important role in the canon of conservation materials. TEOS-based (tetraethyl orthosilicate, tetra alkoxysilane, or KSE) materials are used for many purposes, such as consolidation of the deteriorated rock and the preparation of repair mortars.

Consolidation is one of the main activities in stone conservation. Deterioration of rocks is often caused by the loss of binding forces during long exposure to weathering influences. Consolidation of deteriorated rock material is done by introducing binder material in the rock pores. TEOS-based consolidants produce silica 'bridges' between rock particles and strengthen the stone structurally.

The reaction of TEOS is induced by its hydrolysis and subsequent condensation in the presence of water and a catalyst. The hydrolysis of TEOS may be pushed forward under acid or alkaline conditions (Parashar et al., 2001), but also metal-organic catalysts can be used to accelerate the reaction. The quantity of water and acid catalyst used for partial hydrolysis reaction is an important factor for formulating an ethyl silicate binder system (Liu et al., 2013).

TEOS-based consolidants penetrate easily into porous materials. They can be adapted to the needs of the brittle stone by the TEOS modular system. As andesite stones consist of siliceous minerals, the formation of silica as a binder belongs to the same chemical system as the deteriorated stone. The similar properties of silica from TEOS and the minerals in the rock create good compatibility and long-term stability.

TEOS is known in rock conservation for nearly a century and is very widely used today. Many types of heritage rock such as sandstone (Gupta, 2011), limestone (Pinto \& Rodrigues, 2008), and calcarenite (Zornoza-Indart et al., 2016) were conserved with TEOSbased consolidants, but there is only limited study on andesite rock consolidation.

In restoration work, consolidants of various kinds are used to restore the initial strength of a damaged stone. Most of them have adverse side effects. Organic consolidants (such as acrylic and epoxy resin and silicone resins) have proved to have mainly good performance of reinforcement and water resistance (Badreddine et al., 2020). But their use has shown to have many negative effects, mainly insufficient penetration properties. Organicbased consolidants decrease the water and vapor permeability of the consolidated rock, have differing thermal behavior, and show a glossy appearance. Other consolidants like nano-lime (Otero et al., 2017); (Navarro-Moreno et al., 2021) or sodium silicate show poor in-depth intrusion with all problems, high alkalinity, color changes (nano-lime is white!), or provoke the formation of damaging salts. These side-effects do not apply to TEOS consolidants (Wheeler, 2005).

The use of different repair mortars is at least as important in stone conservation as consolidation (Leisen et al., 2004). The conservation efforts for andesite stone often request 
adapted repair mortar systems, too. For successful mortars, a special mixture of grain sizes of the filler added to the binder is a determining factor. The grain size distribution has to follow a special law to obtain a close packing of filler grains and a reduction of binder volume needed. The addition of particles will increase the performance because of the decrease of gel shrinkage (Ksinopoulou et al., 2012). The addition of particles onto the TEOS mixture improves the cementitious property (Barberena-Fernández et al., 2019). The reaction process of TEOS as a binder in mortars follows the same principles as in stone consolidation.

In the joint project, TEOS was used with andesite aggregates to form repair mortars for andesitic rocks. This mortar was mainly applied for gap and joint filling. The color of mortar for stone restoration is best to be affected by the use of different colored sands or broken stone aggregates. Thus, the use of pigments is almost not necessary. Therefore, different types of andesite stones and natural sands were collected in this study and used as fillers for the different mortars.

This study intends to evaluate the application effectiveness of TEOS-based material on the andesite type rock. It wants to contribute to the broader application of TEOS in heritage conservation and to create a new understanding of the interaction between TEOS and andesite.

The limitation of the TEOS modular system is its application on wet rocks. The water content in the rock matrix reduced the consolidation performance using TEOS-based consolidant, and $0.5 \%$ was the maximum water content allowed to maintain the consolidated rock performance (Cahyandaru et al., 2021). The study to develop rock consolidation material that can be applied to the wet material is the prospect of further research, one of the consolidation alternative is lithium silicate solution.

This paper introduces the application of the TEOS Modular System and the development of repair mortars and gluing techniques. It demonstrates the practical use in the case of an emergency intervention on the big Buddha Head in the KarmawibhanggaMuseum in Borobudur. It describes briefly the holistic approach important for successful conservation interventions.

The TEOS Modular System

In the cooperation project, one of the main topics was the application of the TEOS Modular System with the use and handling of mortars based on TEOS. When TEOS is applied to the stone or used as a binder for mortar, the silicic acid ester TEOS ( $\mathrm{Si}(\mathrm{EtOH}) 4)$ reacts with water $(\mathrm{H} 2 \mathrm{O})$ and forms a strengthening silica gel $(\mathrm{SiO} 2, \mathrm{aq})$ while alcohol $(\mathrm{EtOH} /$ ethanol) is released as a by-product of the reaction:

$$
\mathrm{Si}(\mathrm{EtOH}) 4+4 \mathrm{H} 2 \mathrm{O} \rightarrow \mathrm{SiO} 2, \mathrm{aq}+4 \mathrm{EtOH}(2)
$$

Depending on their composition, the TEOS products have different properties, e.g., the "gel deposition rate" (the quantity of silica gel that is deposited in the pore structure), the speed of the reaction (type, quantity of the catalyst), the addition of solvent(s) (which is not necessarily required), and the addition of so-called "soft segments" for elasticized stone strengtheners. As seen in fig. 1, a weathered stone surface can display different forms of deconsolidation. In the TEOS Modular System pure TEOS is used as a consolidant. When the gaps between the components are wider the bridging properties of pure TEOS are not sufficient and the TEOS product KSE 500STE has to be used. This modification has a gel deposition rate of approx. 50\%, soft segments for a more flexible silica gel and dispersed fumed silica as a filler. If the gaps become even wider, injection mortar systems combined of fine filler grains and KSE 500STE as the binder are the right response. Fig. 2 illustrates how the TEOS Modular System can be used for strengthening the structure of natural stone and for the production of TEOS-based mortars for injection, pointing and washes, using KSE 500 STE with different fillers. 


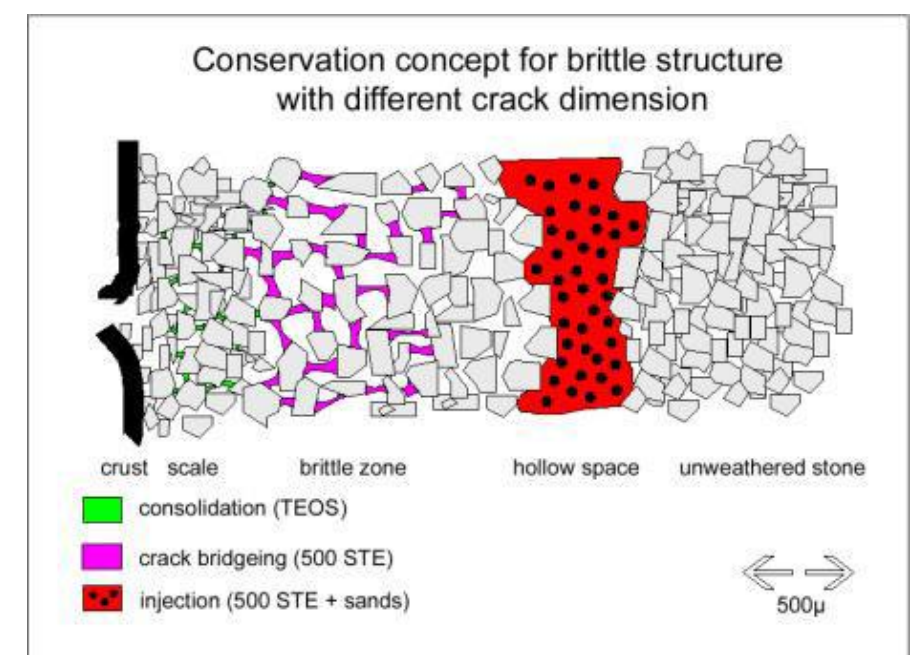

Fig. 1: Depending on the deterioration and crack dimension, different products based on TEOS can be used. Graphic: (Wendler et al., 1996).

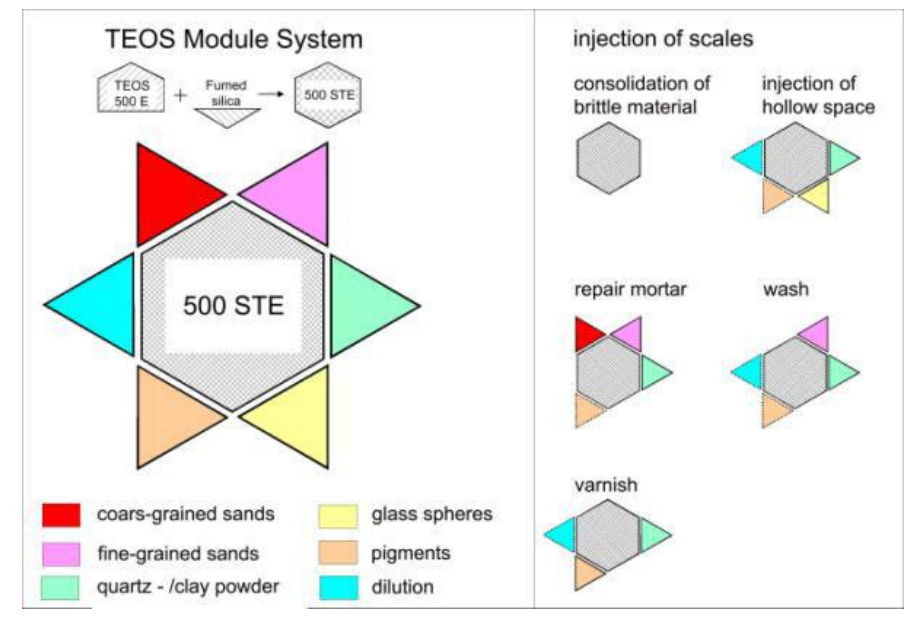

Fig. 2: Schema of the TEOS Module System for different applications in stone conservation. Graphic: (Wendler et al., 1996)

Important information on the TEOS Modular System and the individual components is given in English on the website of Remmers Company (https://en.remmers.com/en).

\section{Preparation of Repair Mortars}

Mortars consist of a binder and fillers or aggregates. For the mortars produced during the study, we combined KSE 500 STE as the binder with different filler fractions. The fillers have a special grain size distribution, calculated by a formula which is called the FULLERparabola.

$\mathrm{Di}=(\mathrm{di} / \mathrm{D}) \mathrm{n} \times 100[\%]$

(1)

Where Di is the amount of grains in \% with a diameter $<$ di (that means the grain falls through a sieve with a sieve sized di) is a grain size diameter which has to be calculated, D for a 
diameter of maximum grain size, and $\mathrm{n}$ is FULLER exponent which describes the form of the used grain.

The mortars produced in the study had a maximum grain size of $0.25 \mathrm{~mm}$ and a FULLER exponent of 0.4. Table 01 shows the calculated grain size distribution.

Table 01. Calculated grain size distribution used in the study

\begin{tabular}{cc}
\hline Grain size $(\mathrm{mm})$ & Amount $(\%)$ \\
\hline $0.125-0.25$ & 24.21 \\
$0.063-0.125$ & 18.17 \\
$<0.063$ & 57.62 \\
Total amount & 100 \\
\hline
\end{tabular}

\section{Gluing in stone conservation}

In stone conservation, gluing is a difficult intervention. The right balance between sufficient and too high adhesive strength is essential. By careful selection of the glue and by adding filler grains the adhesive strength can be adjusted.

The application of adhesives on the complete surface of breakages or exchange parts is not permitted as it causes an impermeable zone inside the stone where the capillarity of the stone is interrupted, and the moisture transport is hindered, as seen in fig. 3(B).

As in most cases in stone conservation, a frictional connection is not necessary. Thus, the dot gluing technique leads to sufficient adherence without negative effects (fig. 3A). Here ready-to-use epoxy resin with perfect viscosity for point glue and a dental top for applying the glue even in small gaps are commercially available.

For the gluing of bigger pieces or for fixing scales, additional mechanical fixation by (e.g. fiberglass) dowels may become necessary. These dowels are glued in a small drill channel in the stone pieces. It is necessary to adjust the viscosity of the glue by adding fumed silica as a thickener. Otherwise, the liquid glue tends to run out of the drill channels and spoil the stone surface irreversibly. To demonstrate the behavior of the different glues with and without a thickener, we applied them to a vertical stone plate during our study.

If the pieces are completely separated, the method of blind dowels can be used (Fig. 4). If it is necessary to drill the hole from the surface, the dowel has to be cut at least $1-2 \mathrm{~cm}$ shorter than the drill hole so that the uppermost $\mathrm{cm}$ can be filled with mortar and the drill hole is nearly invisible from the surface.

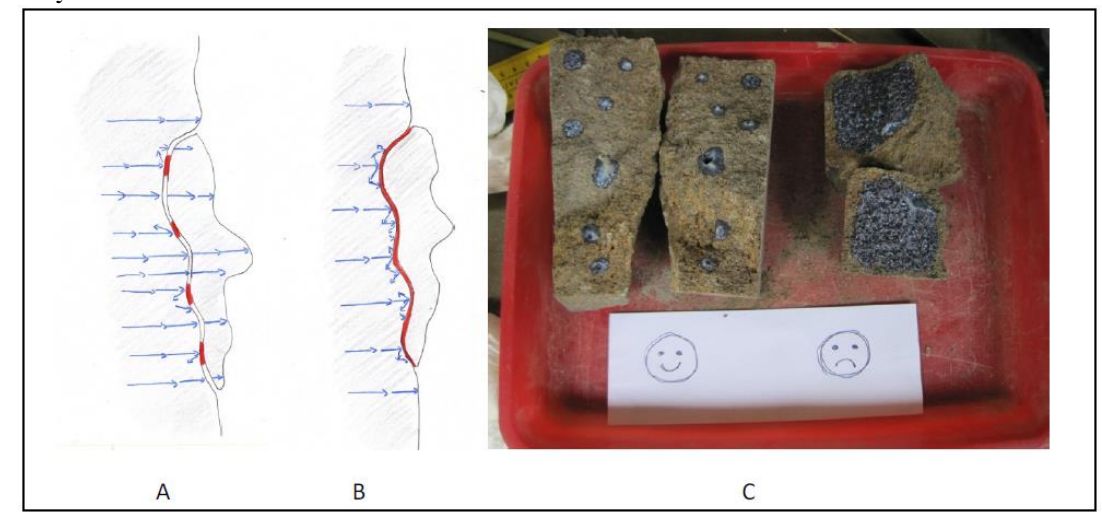

Fig. 3: Glue application in small dots (A), full surface application provokes a dense surface preventing moisture transport $(B)$. $C$ shows the application of the two techniques of A and B (Drawings by Decker \& Prechtel). 


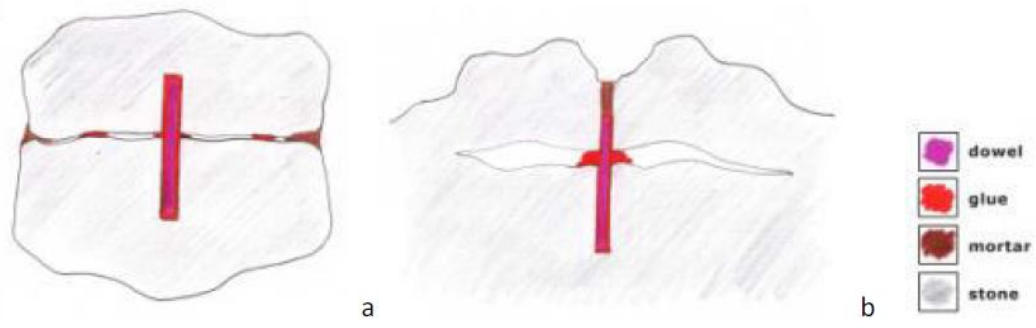

Fig. 4: Fixing with dowels a: blind dowels, b: dowel with drilling through the surface

(Drawings by Decker \& Prechtel).

\section{Development of a conservation conception for the Buddha Head Preparation}

The big Buddha Head at the Karmawibhangga Museum (fig. 5) in Borobudur was in danger to lose parts of its decoration. Three curls had already fallen off and were collected by BCO and more curls were detached. Therefore, it was urgent to secure these endangered parts.

The development of an adapted conservation conception for the Buddha Head started with careful documentation of the stone damages and deterioration patterns (fig. 5). Based on the international ICOMOS ISCS Illustrated Glossary on Stone Deterioration Patterns (ICOMOS, 2008) an individually adapted Glossary was developed for andesite stones at Borobudur Temple, but it can be modified to other Indonesian monuments. The mapping of the Buddha Head showed that three more curls were highly endangered to fall off. They were secured by an emergency intervention fixing these parts with small point glues through the open gaps.

Fig. 5: The big Buddha Head from the
Karmawibhangga Museum in Borobudur
and the mapping of deterioration patterns
showing the endangerment of the object.



developed.

Meanwhile, adapted conservation materials and application techniques were

Following the requirements of the Buddha Head, the main stress was laid on the development of successful repair mortars and gluing procedures.

For application tests at the beginning of the study, several dummies were prepared for practical investigations. Therefore several collected stones were broken artificially to simulate pieces that have to be glued together without and with additional dowels. The joints of the breakages have been carved partly wider to imitate lost areas of stones which could be filled later with stone mortar based on the TEOS Modular System. Additionally, there have been artificial damages and cracks in other stones, which could be used for this practical training, too.

In the following, the process for the development of a conservation conception and application techniques is shown. This holistic approach can be individually modified and then transferred to other objects and monuments.

\section{Practical development of repair mortar systems}

In the TEOS Modular System KSE 500STE from Remmers/Loeningen is used as the binder for mortars. As fillers crushed andesite stone was prepared. For the development of repair mortars for the big Buddha Head, different types and colors of andesite stones were collected from the area around Borobudur. The rocks were crushed by hand using a hammer, a mortar, and a pestle. Afterward, these stone powders were sieved and stored in closable containers by using one container for each kind of grain size fraction and type of sand. Five different colored andesite stone types were crushed and sieved: Andesite Light Grey, Andesite Grey, Andesite Dark Grey, Andesite Red, Andesite Red Grey.

In case of greater demand for repair mortar, a stone crusher and a sieving machine are necessary.

The first task was to produce different colored mortars just by using different types of fillers. Because of the small amount of produced sands, it was only possible to make a small sample of each recipe (fig. 6).

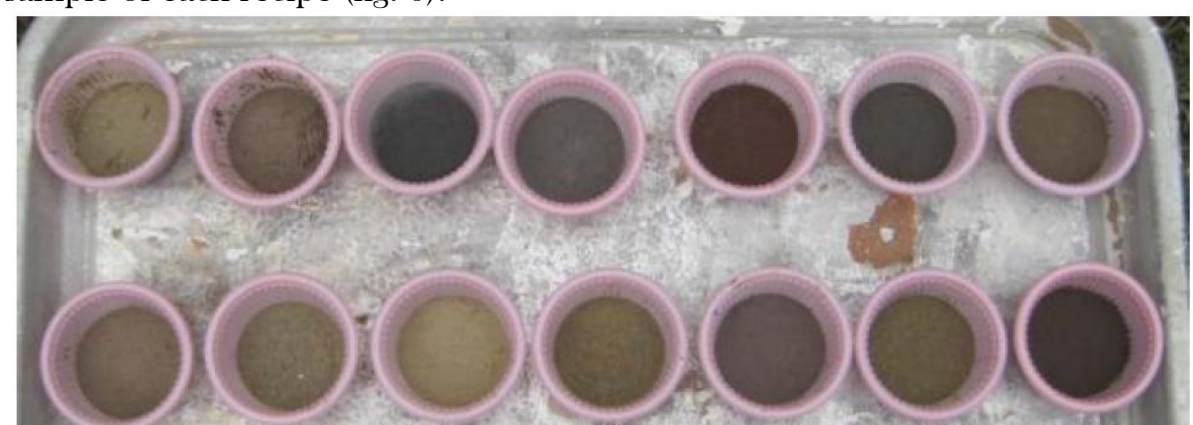

Fig. 6: The color of the mortars is given by the different types of andesite aggregates.

The mortars were applied to small plastic cups for comparison of the color of the recipes. For further investigations, more samples, at least 3 disks and 6 prisms have to be made of each recipe. The molds for these samples were given to BCO (Fig. 7). 


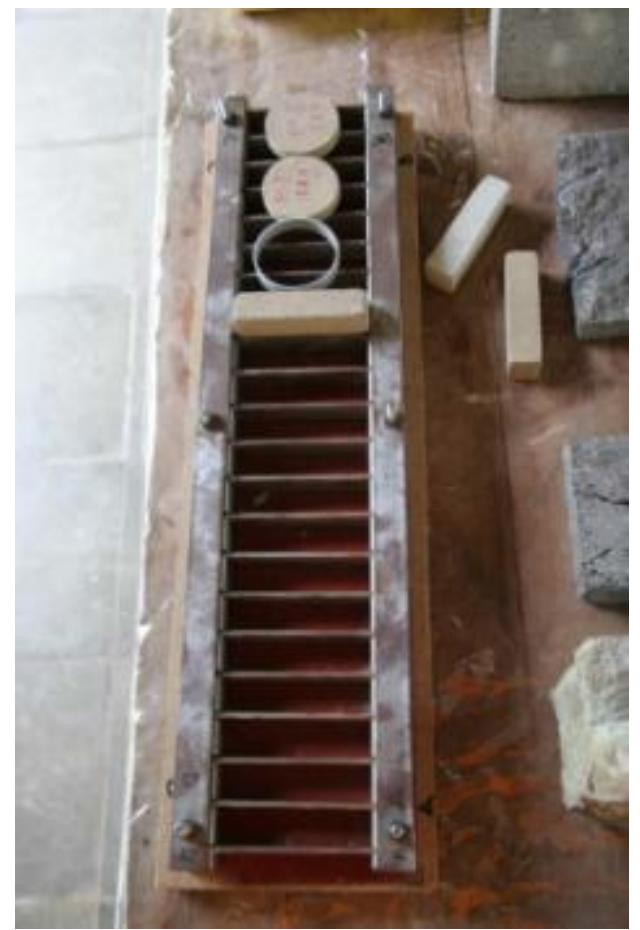

Fig. 7: Mortar samples formed as disks and prisms were prepared for further investigations

After the reaction of the binder, important properties of the different mortar compositions can be determined like capillarity, strength, ultrasound velocity, water vapor diffusion, etc. If necessary, these samples are also appropriate for further treatment like consolidation e.g.

Two recipes were chosen and applied to dummies. It is important to apply the mortar in small steps from the top to the bottom. First, the stone has to be pre-wetted with KSE 300 . Then the mortar can be applied to the gap or hole by using a small spatula. Afterward, the surrounding stone has to be cleaned with a dry spoon or brush. After finishing the work, the stone has to be protected from direct sunshine, rapid drying, and rain during the time of reaction.

\section{Gluing and mortar application on the stone dummies}

Before mortars of the TEOS modular system were applied, a preparatory gluing of the rock breakage was performed. The application of adhesives on the complete surface of breakages or exchange parts is not advisable as it causes a lot of negative impacts to the glued pieces. Therefore, the dot technique as described in fig. 8 was applied.

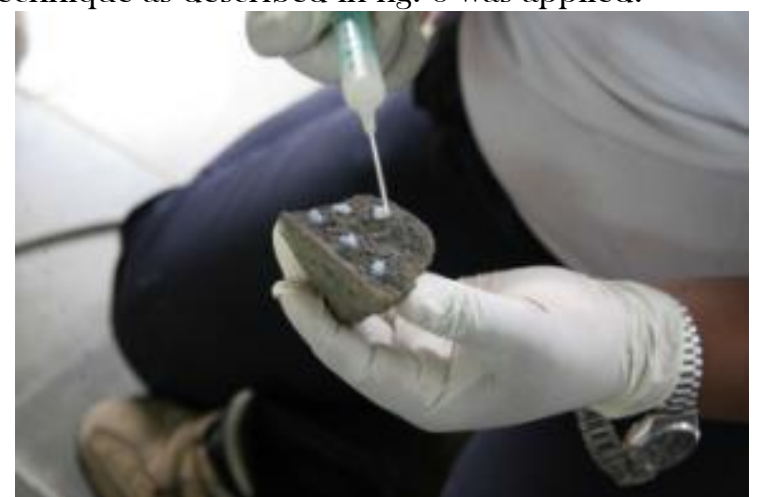

Fig. 8: Dot technique to join broken stone pieces 
After the pieces were put together, the gaps were closed with the TEOS mortars made from a similar color of rock powder. The repair mortar was prepared by mixing $15 \mathrm{ml}$ TEOS (KSE 500 STE) with 50 grams of andesite sand with a specific grain size distribution, as mentioned in the mortar preparation above. The mixture should be prepared immediately before the application.

\section{Exemplary Application on the big Buddha Head}

As the investigation on the big Buddha Head at the Karmawibhangga Museum (fig. 5) in Borobudur showed, it was urgent to secure endangered parts. As part of this study, the intervention of the big Buddha Statue Head was also performed. First, the glass cabin was removed, the state of preservation was investigated, and photos were made for the mapping and documentation. The damage mapping showed that three more curls were highly endangered to fall off. They were secured by an emergency intervention fixing these parts with small point glues through the open gaps (fig. 9a). Afterward, we glued the three collected pieces back to their original position also by application of small dots of adhesive, as shown in Fig 9 (b). After the curls were returned to their original position, the TEOS mortar system was applied in the gaps to obtain the good camouflage of the breakage, as shown in Fig 9 (c).

It is known that the Buddha Head comes from the Wonosobo area. Therefore, a journey to the place of excavation was part of the study.

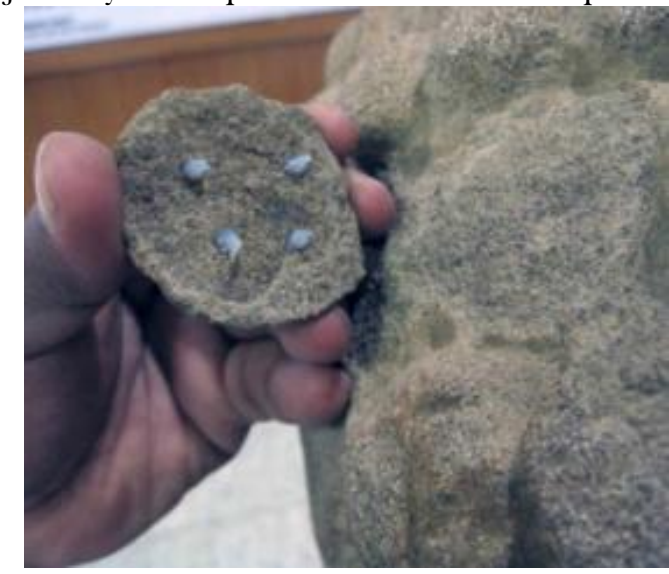

(a)

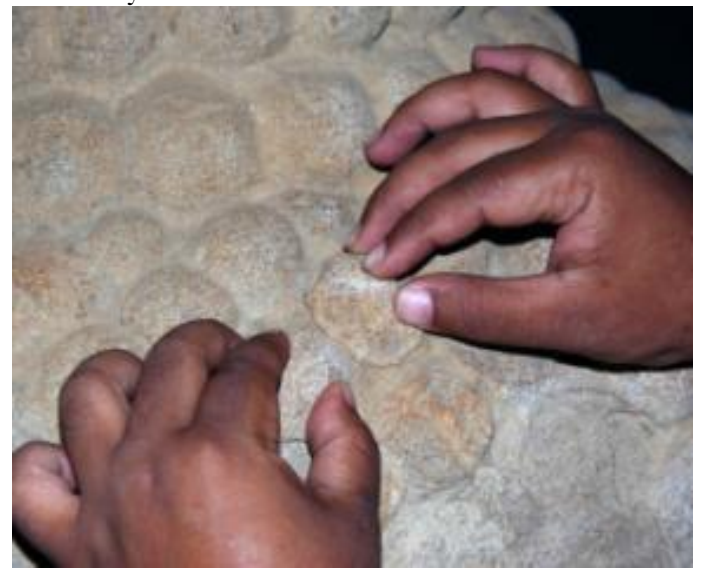

(b)

Fig. 9: (a) The curls were fixed with small dots of glue (b) shows two curls being

\section{CONCLUSION} reattached to the head.

In stone conservation, the TEOS modular system is used for around 25 years for consolidation and repair mortar conception. With this system conservation materials and application forms can be individually adapted to the stone materials and preservation status. Most adverse effects known from other conservation materials are excluded in the TEOS modular system.

In the German-Indonesian cooperation project, this system was successfully applied to the andesite type rock, with a good result due to both chemical and physical properties. The color of the mortar and the compatibility with the original rock color were designed from the rock powder preparation. The good repair was obtained by the combination of dot technique gluing using epoxy resin and the TEOS mortar application in the gaps.

Furthermore, this technique was successfully applied to the andesite rock of the big Buddha Statue Head for the emergency intervention to fix the endangered fragments, and already fallen off pieces. 
The limitation of the TEOS modular system is the application on wet rocks. The study to develop rock consolidation material that can be applied to wet material is the prospect of future research. More research to improve the consolidation performance by additional particle modification on consolidation materials is also needed.

\section{ACKNOWLEDGMENT}

The authors acknowledge the Cultural Preservation Programme of the German Federal Foreign Office and the UNESCO Office Jakarta for the funding of the Borobudur Conservation Project to conduct this study at Borobudur, Indonesia. The authors also acknowledge the Borobudur Conservation Office laboratory team for the active technical support during the study. The team members are: Iskandar M. Siregar, Leliek Agung Haldoko, Ahmad Mudzakir, Yudi Atmadja H.P, Al. Widyo Purwoko, Wahyudi, Basuki Rahmad, Arif Gunawan, Sri Wahyuni, Rony Muhammad, Heri Yulianto, and Panggah Ardiyansyah. Our thanks also go to the German team members Eberhard Wendler Ph.D., Dipl.-Rest. Manuela Prechtel M.A. and Dipl. Rest. Emmeline Decker M.A. for their important input to the project work and this article.

\section{REFERENCE}

Badreddine, D., Beck, K., Brunetaud, X., Chaaba, A., \& Al-Mukhtar, M. (2020).

Nanolime consolidation of the main building stone of the archaeological site of Volubilis (Morocco). Journal of Cultural Heritage, 43, 98-107.

Barberena-Fernández, A. M., Blanco-Varela, M. T., \& Carmona-Quiroga, P. M. (2019). Use of nanosilica- or nanolime-additioned TEOS to consolidate cementitious materials in heritage structures: Physical and mechanical properties of mortars. Cement and Concrete Composites, 95, 271-276.

Cahyandaru, N., Wahyuni, E. T., \& Nuryono, N. (2021). Performance Improvement of Tetraethylorthosilicate Consolidated Andesite Rock by Adding Titanium Tetraisopropoxyde and Silica Particles. Indonesian Journal of Chemistry.

Gupta, S. P. (2011). Modification of The Physical Properties of Deteriorated Stone by Chemical Consolidation Treatment. International Journal of Conservation Science, 2(4).

ICOMOS, I. (2008). Illustrated glossary on stone deterioration patterns. Icomos, Paris.

Ksinopoulou, E., Bakolas, A., Kartsonakis, I., Charitidis, C., \& Moropoulou, A. (2012). Particle modified consolidants in the consolidation of porous stones. Proceedings of the 12th International Congress on the Deterioration and Conservation of Stone Columbia University, New York, NY, USA.

Leisen, H., Plehwe-Leisen, E. von, \& Warrak, S. (2004). Succes and limits for stone repair mortars based on tetra ethyl silicate-conservation of the reliefs at Angkor Wat Temple, Cambodia. Proceedings of the 10th International Congress on Deterioration and Conservation of Stone; Vol. 1, p-331.

Liu, R., Han, X., Huang, X., Li, W., \& Luo, H. (2013). Preparation of three-component TEOS-based composites for stone conservation by sol-gel process. Journal of SolGel Science and Technology, 68(1), 19-30. 
Navarro-Moreno, D., Martínez-Arredondo, A., García-Vera, V. E., Lourdes GutiérrezCarrillo, M., Antonio Madrid, J., \& Lanzón, M. (2021). Nanolime, ethyl silicate and sodium silicate: Advantages and inconveniences in consolidating ancient bricks (XIIXIII century). Construction and Building Materials, 277, 122240.

Otero, J., Charola, A. E., Grissom, C. A., \& Starinieri, V. (2017). An overview of nanolime as a consolidation method for calcareous substrates. Ge-Conservación, 1(11), 71-78.

Parashar, G., Srivastava, D., \& Kumar, P. (2001). Ethyl silicate binders for high performance coatings. Progress in Organic Coatings, 42(1-2), 1-14.

Pinto, A. P. F., \& Rodrigues, J. D. (2008). Stone consolidation: The role of treatment procedures. Journal of Cultural Heritage, 9(1), 38-53.one consolidation: The role of treatment procedures. Journal of Cultural Heritage, 9(1), 38-53.

Wendler, E., Charola, A. E., \& Fitzner, B. (1996). Easter Island tuff: Laboratory studies for its consolidation. Proceedings of the 8th International Congress on Deterioration and Conservation of Stone, 30, 1159-1170.

Wheeler, G. (2005). Alkoxysilanes and the Consolidation of Stone. Getty Publications.

Widati, A. A., Abdulloh, A., Khasanah, M., Kusumawati, R., \& Cahyandaru, N. (2017). Fabrication of Silica-Titania as Consolidant and Self Cleaning for The Conservation of Andesite Stone. International Journal of Conservation Science, 8(3).

Zornoza-Indart, A., Lopez-Arce, P., Leal, N., Simão, J., \& Zoghlami, K. (2016). Consolidation of a Tunisian bioclastic calcarenite: From conventional ethyl silicate products to nanostructured and nanoparticle based consolidants. Construction and Building Materials, 116, 188-202. 